\title{
AN ASSESSMENT OF THE RESPONSE PREPAREDNESS FOR NATURAL DISASTER AMONG ACCREDITED HOSPITALS IN YOGYAKARTA USING HOSPITAL SAFETY INDEX
}

\author{
Mufidatullaily, Sagiran, Arlina Dewi, Sri Sundari, Muallim Hawari
}

Masters Program in Hospital Management, Universitas Muhammadiyah Yogyakarta

\begin{abstract}
Background: Indonesia is a country prone to natural disasters, especially earthquakes and floods. Hospital is the healthcare centers whose play a significant role in decreasing disaster mortality rate. Hospital Safety Index (HSI) is a tool devised by World Health Organization (WHO) to measure the level of hospital preparedness for disasters. HSI is also one of the criteria that must met the National Hospital Accreditation Standards (NHAC), set by the government. This study aimed to investigate the assessment of the response preparedness for natural disaster among accredited hospitals in Yogyakarta using hospital safety index

Subjects and Method: A qualitative study was conducted in several hospitals that have been accredited by the NHAC in Yogyakarta Province. Some persons in charge in the structural part of the disaster management system were selected as key informants for this study. The main theme of this study was the preparedness for natural disaster among accredited hospitals. The data were collected using HSI checklist from WHO. The data were analyzed descriptively.

Results: The Hospital Safety Index has been used as a tool for assessment of disaster preparedness at hospitals in Yogyakarta. Its measurement is not time-consuming, easy to use, and low in cost. All hospitals fully accredited by NHAC had high HSI scores.

Conclusion: The Hospital Safety Index devised by WHO can be used to asses hospital preparedness to respond natural disaster.

Keywords: hospital safety index, national hospital accreditation standard, natural disaster management

\section{Correspondence:}

Mufidatullaily. Masters Program in Hospital Management, Universitas Muhammadiyah Yogyakarta/ Adi Sucipto Kimia Farma Clinic. Jl. Laksda Adisucipto No. 63A, Ambarukmo, Caturtunggal, Kecamatan Depok, Kabupaten Sleman, Daerah Istimewa Yogyakarta. Email: mufidatullaily1308@gmail.com. Mobile: 081326506786.
\end{abstract}

The $6^{\text {th }}$ International Conference on Public Health

Best Western Premier Hotel, Solo, Indonesia, October 23-24, 2019 | 248

https://doi.org/10.26911/the6thicph.04.10 